\section{NOVA STILES INTO A NFW ORBT}

NEW YORK - The newly redefined partnership arrangements between SmithKline Beecham (SB, London) and Nova Pharmaceutical (Baltimore, $\mathrm{MD})$ for developing and marketing central nervous system (CNS) drugs (Bio/Technology 8:489, June '90) will change Nova's appearance. SB has cut off its funding to the partnership, and in its stead has given Nova rights to the products under development, plus existing psychiatric drugs and a sales force to market them. Thus, near-term revenue potential has grown, but new questions loom about financing longer-term projects.

Beecham, prior to its merger last year with SmithKline Beckman, already had an active effort in developing CNS drugs. Keeping that effort going and also funding (and managing) the SmithKline/Nova partnership would have been redundant. SB also is faced with a heavy debt-service burden, and the 1987 arrangements with Nova called for it to contribute $\$ 24$ million in funding to the partnership. Something had to give.

Nova, according to president Hans Mueller, thinks the unwinding of SB's commitment yields a new opportunity to implement an overseas partnering strategy. "It has always been my dream to do that," Mueller says, and the relationship with $\mathrm{SB}$-both in kinin antagonists as asthma treatments-had been an impediment. Now, all the technology is owned by Nova or the Nova/SB partnership (which, as part of the new relationship with SB, Nova now controls). The company plans to finance by partnering off major packages in CNS and pain and inflammation to Japanese and European companies in return for funding of its U.S. clinical work.

The main question is what value Nova will get out of the four psychiatric drugs-Thorazine, Stelazine, Eskalith, and Parnate-SB has transferred. They netted SB $\$ 34$ million in revenues last year, but competition from new compounds looms. Mueller believes that "people who haven't switched off these products yet, likely will not." He also thinks that Nova will be able to pay closer attention to managing the sales force, which came CNS and with applications for brady- from SB with the drugs. And Nova plans to offset any erosion in unit sales by increasing prices.

With almost all of its proprietary products in preclinical or early-stage human trials, Nova will have to come up with new sources of capital regardless of the success of the existing psychiatric line. Mueller acknowledges that there is "no question that, in due time, we will have to raise cash," to commercialize its CNS antagonists. But he also points out that "for partnerships, one prefers to have clinical data." Pain and inflammation, therefore, appear to be the areas where partnerships may emerge first. Nova has three projects already in the clinic, and back-ups to its lead bradykinin antagonists.

The public market is an unlikely source of funds, at least for a while. By 1987, Nova's market capitalization had exceeded $\$ 600$ million-"an obscene number," admits Mueller. When the market crashed, Nova fell hard. "The analysts have not yet come back," he notes, "their business is tougher now, and they're more conservative." -Mark Ratner

\title{
IMATear Vicants
}

\section{NFW VECTOR COMBATS NFWCASTLE ON TIME}

LONDON-Epidemics of Newcastle disease continue to threaten the poultry industry, both in countries that control the disease by slaughtering infected flocks and in those that rely on the present generation of vaccines, which do not always afford solid protection. Now, a vaccine that uses fowlpox virus (FPV) as a vector to carry genes coding for Newcastle disease virus (NDV) antigens can completely protect chickens against a virulent strain of the disease.

The new vaccine has been developed by Michael Boursnell and colleagues at the Houghton Laboratory of the Agricultural and Food Research Council's Institute for Animal Health. The British Technology Group (BTG, London), a technology transfer organisation established to develop products and processes arising from U.K. universities and research councils, has financed their work in part. BTG has patented gene constructs coding for antigenic determinants of NDV and (infectious bronchitis virus) in recombinant viruses developed at Houghton.

As with recombinant vaccines based on vaccinia, Boursnell and coworkers introduced foreign genes into the vector by homologous recombination between sequences flanking the gene and sequences in the FPV genome. They inserted the haemagglutinin-neuraminidase (HN) gene from the Beaudette strain of NDV, under the control of the vaccinia virus $\mathrm{p} 7.5$ promoter, into a nonessential gene in the terminal inverted repeat region of FPV. The gene was fully expressed in tissue culture: They used Western blotting and a specific monoclonal antibody to demonstrate the presence of a protein of the correct size for glycosylated $\mathrm{HN}$ protein. When inoculated into chickens, the vaccine elicited the production of antibodies that recognised $\mathrm{HN}$ isolated from purified NDV virions. Inoculated birds were totally resistant to challenge with virulent NDV.

Boursnell and his colleagues have now engineered a second recombinant virus by inserting the $F$ (fusion) gene of NDV into FPV. Although this did not lead to detectable levels of the appropriate protein when the virus was grown in tissue culture, it pro- duced equally solid immunity when administered as a vaccine.

Announcing these developments recently, Frederick Bourne, the director of the Institute for Animal Health, said that the work has established that FPV can be used to deliver "any one of a number" of foreign genes coding for immunogenic proteins. The Houghton group has carried out a considerable amount of work on the organisation of the FPV genome, including the identification of its topo-isomerase gene. Sequencing has shown that this is 56 percent homologous with its vaccinia homologue. Boursnell and co-workers have also located, in the FD8 and FD9 genes within the central region of the FPV genome, non-essential sites into which foreign genes can be placed. They believe that these will be useful in further work on the construction of polyvalent vaccines. The genetic and environmental stability of FPV, and the simplicity with which it can be cultured, also commend this organism as a safe vehicle to express protective antigens in non-avian species. -Bernard Dixon 